\title{
CONSUMER ETHNOCENTRISM AND CONSUMER ASSOCIATIONS WITH SLOVAK BRANDS
}

\author{
Lucia Vilčeková ${ }^{1}$
}

\begin{abstract}
This paper describes the perception of Slovak consumers toward domestic and foreign brands and examines their associations with Slovak brands. The introduction to country of origin in marketing is provided, followed by a brief description of consumer ethnocentrism and consumer animosity; then description of research methodology is mentioned; and finally, research results are presented.

The representative research was conducted in 2013 over a sample of 1,067 Slovak consumers over the age of 16. To capture the spontaneous reactions to Slovak brands, the respondents were asked to name what comes to their mind when they hear the expression "Slovak brand." Slovak consumers associate domestic brands with quality, tradition, fair prices, and Slovakia. Their primary feelings toward Slovak brands are mostly positive. If they have negative perception, that is only because domestic products are not often available in stores and there is a lack of Slovak brands. Moreover, the consumers were presented with a list of 27 statements concerning their attitude toward domestic and foreign brands and their brand buying behavior. Based on the research results, Slovak consumers can be observed as very brand-oriented and often possess a strong brand loyalty when making purchasing decisions. Slovak consumers are not necessarily patriotic as far as purchasing is concerned. The main reason for buying Slovak products is only to support the economy and the Slovak consumers are very aware of the benefits of supporting domestic production. Nevertheless, consumer ethnocentrism is not typical for Slovaks.
\end{abstract}

JEL Classification Numbers: M310, DOI: http://dx.doi.org/10.12955/cbup.v2.452

Keywords: brand loyalty, consumer ethnocentrism, domestic brands, economic crisis, foreign brands, globalization, Slovak consumers

\section{Introduction}

There are products from various origins being offered to customers, which is a consequence of globalization and merging and connecting markets. The formation of global economy has noticeably widened the presence of foreign products in domestic markets. This has stimulated an interest in examining the role of country of origin and its consequences on consumer behavior. It can be considered a cue that is capable to summarize information on products, brands and firms from different countries. Therefore, country of origin can be seen as one element of a brand that helps consumers to associate the brand with a specific country. At times, product origin may create a barrier to the trade of goods and services within or between countries. Consumer preferences for foreign and domestic products could be influenced by trust in foreign firms, consumer ethnocentrism and prejudice toward a specific country (Torres \& Gutiérrez, 2007).

Country of origin and customers' perception of goods and services are closely associated with consumer ethnocentrism and consumer animosity. Consumer Ethnocentrism was first introduced, by William G. Sumner (Sumner, 1906), as "the technical name for the view of things in which one's own group is the center of everything, and all others are scaled and rated with reference to it." In marketing, we can say that consumers prefer to buy products from their home country instead of foreign products. According to Shimp \& Sharma (1987), highly ethnocentric consumers have the feeling that buying foreign products is wrong because of the damage it would bring to the local economy. Animosity is a variable that has recently been incorporated by marketing science and refers to the economic consequences of human emotional responses. Klein, Richard, \& Morris (1998) introduced the concept of consumer animosity by to describe negative consumer emotions related to international hostile events between nations. If consumers think a foreign nation is inflicting damages on their country, they will be inclined to show animosity toward that specific country.

According to Bandara \& Chovancová (2012), direct effect of consumer ethnocentrism is to stimulate customers to purchase domestic products as opposed to foreign products. More specifically, consumers

\footnotetext{
${ }^{1}$ Lucia Vilčeková, Comenius University, Bratislava, Slovakia, lucia.vilcekova@ fm.uniba.sk
} 
who are extremely ethnocentric are likely to be more discriminatory toward foreign products than those who do not hold such beliefs. Those who believe that it is wrong to buy foreign products also tend to perceive those goods as lower in quality than domestic goods; ethnocentric consumers prefer domestic goods not only because of economic or moral beliefs, but also because they believe that their own country produces the best products (Akdogan, Ozgener, Kaplan, \& Coskun, 2012).

Image of the country of origin can be seen as an instrument relevant to purchasing behavior and companies can use country image as a driver for their product sales. Consumers use this image as a mean of evaluating products, characteristics, and abilities of a company (Jones, Hesterly, \& Borgatti, 1997). Image of a specific country can help consumers to apply information about the country on a product and its quality, benefits, promises and values, especially when the product attribute is unknown. This image determines the perceived quality of a country's exports, and also the type of goods in which a nation specializes. Consumers may also generalize their attitudes and opinions on a country's products based on familiarity, general characteristics and past experience with the country of origin, e.g. Japanese technologies, American cars, and etc. (Torres \& Gutiérrez, 2007). It is important for marketers to examine such associations with country of origin in order to determine the basic consumer attitudes in order to create better product values. For example, products labeled "Made in Germany" or "Made in France" are generally accepted more positively than those that are, for example, "Made in Bangladesh" (Roth, Diamantopoulos, \& Montesinos, 2008).

\section{Material and Methods}

The objective of this study is to examine the attitude of Slovak consumers toward domestic and foreign brands. In order to achieve this goal, primary research was conducted with 1,067 respondents who were selected based on quota sampling. The basic idea of quota sampling is to set a target number of completed interviews with specific subgroups of the population of interest (Lavrakas, 2008). The subgroups of this research are age, income, gender, and education; they reflect the proportion in Slovak consumer demographic of age 16 and older. More than 1,200 questionnaires were distributed and 1,067 were taken into the final analysis, giving us the permissible error of $3 \%$ and confidence level of $95 \%$ for the research results. Data were collected from January to April 2013 in Slovakia and the instrument for data collection was a questionnaire. Respondents were presented with a list of statements concerning their attitude towards domestic and foreign brands and their brand perception. Likert scales, as a very common and easy tool for measuring attitudes, were used in the questionnaire.

The data were evaluated in R, a statistical analysis software; whereas graphics and open-ended questions are presented in forms of tag clouds for better visualization. The research results are presented and described in the following section.

\section{Research results}

To be able to determine the associations with Slovak brands, respondents were asked to name what comes to their mind when they hear the expression "Slovak brand." In order to identify the attitude, concrete brand names recalled by the respondents were eliminated and only their statements are presented in Figure 1. The most frequent expression is "quality for reasonable price" (35\%), followed by "the best quality" (30\%). Among the top statements are also "fair price" (16\%), "Slovakia" (12\%), "very good quality" (8\%), "excellent" (5\%), and "homemade" (2\%). All of these statements are positive and correlate with strong patriotism with high quality of domestic goods. On the other hand, negative associations are represented by opinions that Slovak products are "cheap products" $(6 \%)$, that there is "not enough Slovak goods in stores" (5\%) and consumers feel "lack of domestic brands" (4\%) and that Slovak products are "often not available" (2\%). Other statements reveal that Slovak consumers associate domestic brands with their "childhood," "milk industry," "farmers' products," "good taste," "supporting 
Slovak economy," and "Made in Slovakia." Most of the expressions are strongly positive and Slovak consumers regard domestic brands as something good, memorable, reliable, and high in quality.

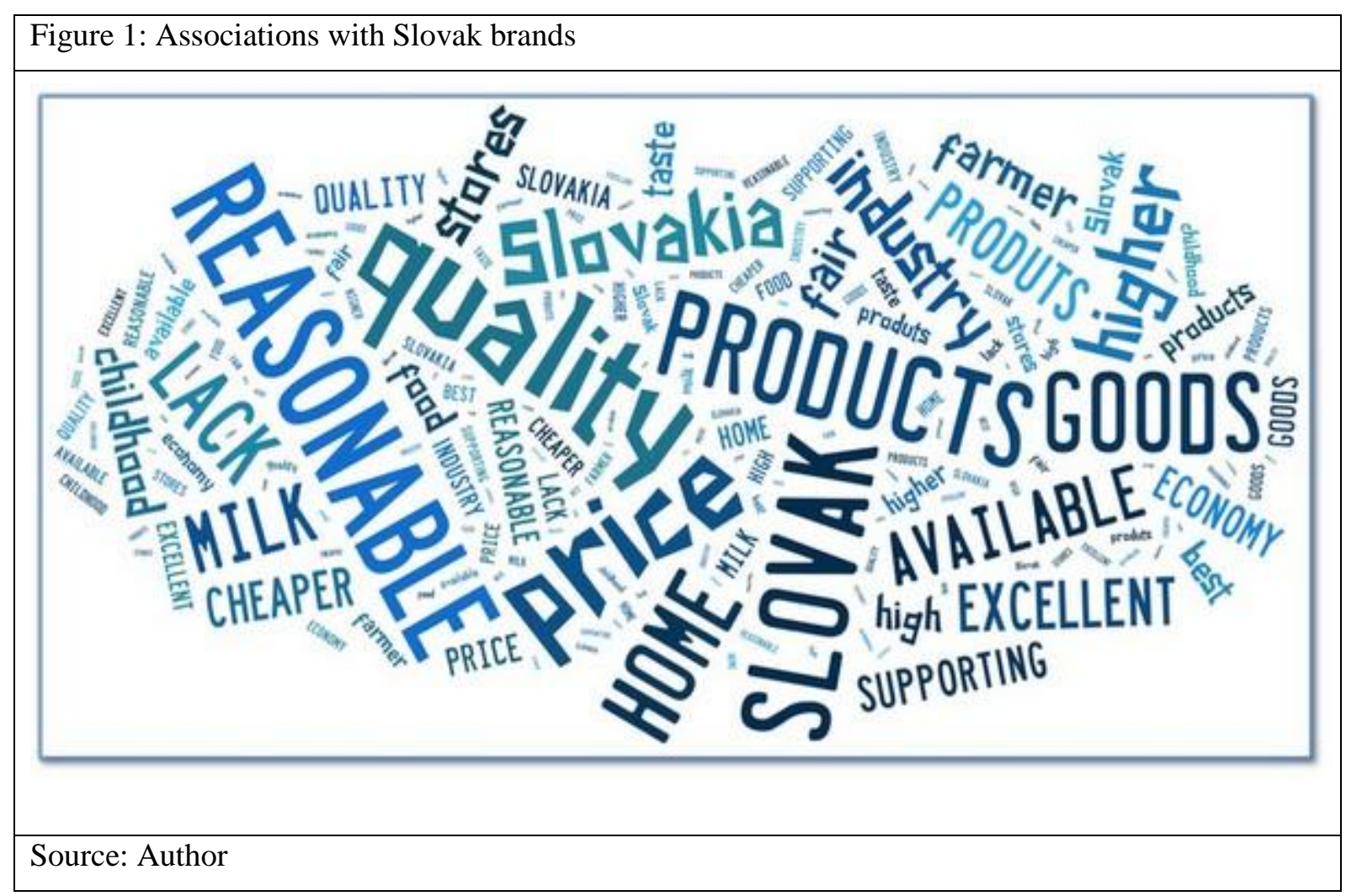

In order to evaluate consumer ethnocentrism and attitude of Slovak consumers toward domestic and foreign brands, the respondents were presented with 27 statements ranging from "strongly agree" (2) to "strongly disagree" (-2). The responses are shown in Table 1.

Concerning the attitude toward domestic brands, Slovak consumers agree that Slovak products are high quality products, but there exists only a small variety of Slovak brands for certain products in the stores. Nevertheless, they tend to prefer Slovak products in their purchases because they like Slovakia and they want to support the country's economy. Slovaks trust domestic brands more than they do of foreign origin and they usually buy foods that are "Made in Slovakia."

As for the foreign brands, Slovaks think they are more readily available and they usually buy consumer products, footwear, and textiles of foreign origin. Consumers do not think that foreign brands do have better quality than Slovak brands.

General trend of Slovaks' perception and behavior toward brands can be summarized as follows:

1. Consumers do have a certain degree of brand loyalty; they are not critically concerned with the brand origin, but are still aware of it.

2. They are brand-oriented and they base their purchasing decision on this attribute.

3. They are not willing to pay more for Slovak-made products, but they do not hesitate to do so on their favorite brands.

4. The consumers do have some interest in the brand origin and they are willing to take the time to research the origin of products they wish to purchase.

5. Brands play an important role for Slovaks, but the consumers are sometimes confused with a great variety of brands. 
CBU INTERNATIONAL CONFERENCE ON INNOVATION, TECHNOLOGY TRANSFER AND EDUCATION February 3-5, 2014, Prague, CZeCh Republic

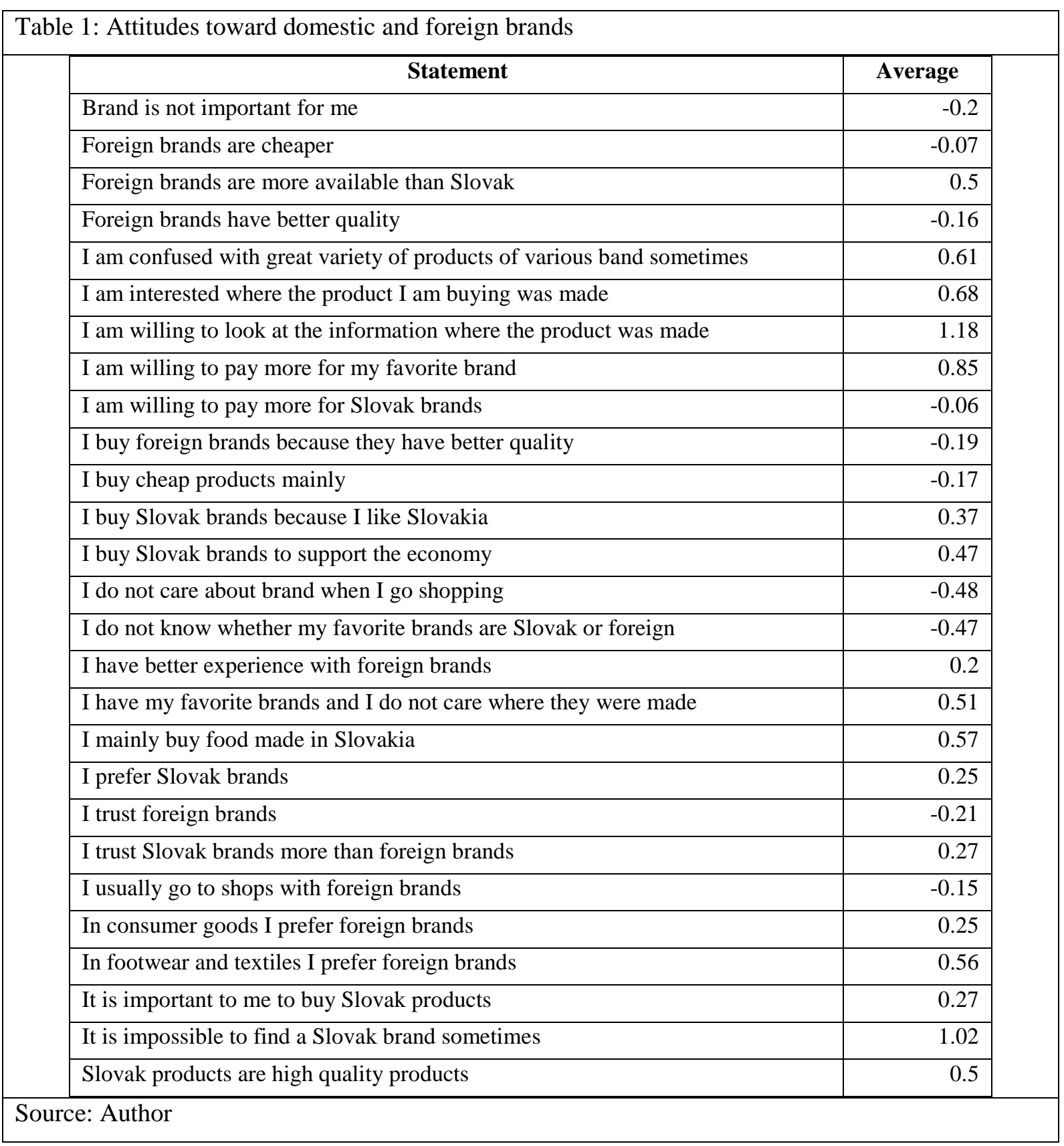

\section{Conclusion}

The influence of country of origin on brand buying behavior has been studied for decades. But in times of globalization, when products are designed in one country, manufactured in another and assembled in another one, consumers are confused and often struggle to identify or recognize domestic products. As Torres \& Gutiérrez (2007) pointed out, "globalization has increased the opportunities for companies to distribute their goods to consumers all over the world. At the same time, consumers are able to choose from a broad range of products and services in almost any category. International product adaptation makes it difficult to differentiate."

Slovak consumers are considered to be brand-oriented. Marketing experts stated that the economic crisis has had some effect on perception of Slovak consumers toward brands-the belief in certain brand names and their promise of quality grew stronger, while the consumers became more price sensitive when purchasing products and expecting higher values in return. 
The crisis strengthened the relation of Slovaks to traditional and established brands. Slovaks look for a certain guarantee of quality and reliability. And traditional brands provide this exact promise (Liptáková, 2011).

Slovak consumers are not as patriotic when it comes to purchasing and retailers have already begun to notice that Slovak consumers are becoming more price sensitive due to the worsening of the economic situation; they are becoming more open-minded to foreign brands. This is a result of both a decline in purchasing power of the Slovaks and a lack of consumer patriotism that was not strongly established in Slovakia. Based on surveys conducted by GFK in 2011, Slovak consumers have a strong interest in purchasing domestic products, but it is questionable whether they actually purchase them when shopping (Liptáková, 2012).

Slovak consumers associate domestic brands with quality, tradition, fair prices and Slovakia. Their intrinsic feelings toward Slovak brands are mostly positive. If they feel otherwise, that is because domestic products are not often available in stores and there is a lack of Slovak brands. Slovak consumers are generally brand-oriented; they only care about specific brands they buy regardless of the price. As far as their favorite brands are concerned, country of origin is irrelevant for them and they are willing to pay more money for it. On the other hand, the main reason for buying Slovak products is to support the economy and we can say that Slovak consumers are greatly aware of these benefits. Nevertheless, consumer ethnocentrism is not typical for Slovaks. During the past 20 years, many companies have undergone a privatization by multi-national companies that have "domesticated" international products in Slovakia. Consumer ethnocentrism also depends on the share of domestic production compared to foreign products. There are certain industries in Slovakia where this share is in favor of domestic production-food industry. However, there are many products where consumers are forced to buy foreign brands, due to the lack of Slovak production, e.g. electronic devices, consumer goods, clothing, etc.

To raise the awareness of consumers about the benefits of purchasing domestic products, the participation of government and manufacturers is needed. There are several institutions in Slovakia that support domestic production. Industrial Property Office of the Slovak Republic, a central state administration body responsible for industrial property protection; Slovak Association for Trademark Products that protects and promotes the common interests of manufacturers of branded products; Ministry of Agriculture and Rural Development with a program to label domestic agricultural and food products called "Quality Label SK;" Association of Trade and Tourism (ZOCR) introduced an initiative "Quality from Our Regions" to increase Slovak consumers' awareness of domestic products. Promoting a positive attitude toward domestic product is beneficial and there is a need to invest in consumers' education to support Slovak economy in times of global economic crisis.

\section{Acknowledgement}

This article has been elaborated as one of the outcomes of research project VEGA 1/1051/11 "Analysis of the strategic process of brand building and brand management in the context of homogenization and individualization of consumer needs."

\section{References}

Akdogan, M. S., Ozgener, S., Kaplan, M., \& Coskun, A. (2012). The Effects of Consumer Ethnocentrism and Consumer Animosity on the Re-Purchase Intent: The Moderating Role of Consumer Loyalty. Emerging Markets Journal, 2(1). doi:10.5195/emaj.2012.15

Bandara, W. M. C., \& Chovancová, M. (2012). Consumer Ethnocentrism and Attitudes Towards Foreign Beer Brands: With Evidence from Zlin Region in the Czech Republic. Journal of Competitiveness, 12(2), 3-19.

Jones, C., Hesterly, W. S., \& Borgatti, S. P. (1997). A general theory of network governance: Exchange conditions and social mechanisms. The Academy of Management Review, 22(4), 911-945. 
Klein, J. G., Richard, E. \& Morris, M. D. (1998). The Animosity Model of Foreign Product Purchase: An Empirical Test in the People's Republic of China. Journal of Marketing, 13(62), 89-100.

Lavrakas, P. (2008). Encyclopedia of Survey Research Methods. doi:10.4135/9781412963947

Liptáková, J. (2011). Brand loyalty continues to reign among Slovaks. Retrieved from http://spectator.sme.sk/ articles/view/41335/24/brand_loyalty_continues_to_reign_among_slovaks.htm

Liptáková, J. (2012). Seeking patriotic buyers in Slovakia. The Slovak Spectator, 4, 6-9.

Roth, K. P., Diamantopoulos, A., \& Montesinos, A. (2008). Home Country Image, Country Brand Equity and Consumers' Product Preferences: An Empirical Study. Management International Review, 48(5), 577-602.

Shimp, T., \& Sharma, S. (1987). Consumer ethnocentrism: construction and validation of the cetscale. Journal of Marketing Research, 14(1), 280-289.

Sumner, W. G. (1906). Folkways: The sociological importance of usages, manners, customs, mores, and morals, NY: Harper \& Row.

Torres, N. H. J., \& Gutiérrez, S. (2007). The purchase of foreign products: The role of firm's country-of-origin reputation, consumer ethnocentrism, animosity and trust. Retrieved from http://gredos.usal.es/jspui/bitstream/ 10366/75189/1/DAEE_13_07_Purcching.pdf 